\title{
EFFECTS OF TILLAGE SYSTEM AND FORECROP TYPE ON FREQUENCY OF Fusarium culmorum AND F. avenaceum OCCURRENCE ON CULM BASE OF SOME WINTER WHEAT (Triticum aestivum L.) CULTIVARS
}

\author{
Ryszard Weber'1, Włodzimierz Kita² \\ ${ }^{1}$ Institute of Soil Science and Plant Cultivation, State Research Institute; \\ Department of Herbology and Soil Tillage Techniques, \\ Orzechowa 61; 50-540 Wrocław, Poland; e-mail: rweber@iung.pulawy.pl \\ ${ }^{2}$ University of Environmental and Life Sciences; Department of Phytopathology, Wrocław, Poland
}

Received: 13.07.2009

\begin{abstract}
In the years $2001-2003$, there were analyzed relations between the number of Fusarium culmorum and $F$. avenaceum, fungi found on culm base parts of stalks of seven winter wheat cultivars, and preceding crop type as well as the cultivation system. The research was carried out in Poland, on light soil plots of a Lower Silesia-based experimental station subordinate to the Institute of Soil Science and Plant Cultivation (IUNG). The loglinear and correspondence analyses proved varying immunity of particular wheat cultivars to $F$. culmorum and $F$. avenaceum fungi. There were also observed significant differences in Fusarium diseases of wheat as dependent on precipitation and temperature in the growing season. The Kobra cultivar was highly resistant to $F$. avenaceum. The lowest amounts of $F$. culmorum fungi were detected in the culm base parts of the Izolda cultivar. The cultivation of corn, as a preceding crop for oats and for spring wheat, did significantly differentiate varieties of fungi in the cultivation systems examined. In the plough cultivation system, wheat was mainly infected by Fusarium culmorum, whereas in direct sowing, particular cultivars of wheat were mostly infected by $F$. avenaceum.
\end{abstract}

Keywords: culm base diseases, tillage system, Fusarium, winter wheat cultivars

\section{INTRODUCTION}

Recently, fusarium diseases (scab) of wheat ears have become very common all over the world. Considerable diversity of Fusarium ssp. makes fungi control in wheat plantations very difficult. Currently, Fusarium culmorum, $F$. graminearum, $F$. avenaceum, $F$. poae and Microdochium nivale prevail in European countries (D o o h a n et al. 2003). Wheat sprout infection reduces crops by $7-17 \%$. The infection of plant roots and stalks in their later stage of development results in 10-30\% crop loss, while infection of ears by Fusarium fungi can cause $30-70 \%$ loss (M a r $\mathrm{t}$ in and Johnston, 1982; In ch and Gil bert, 2003). The application of plant protection measures can reduce the occurrence of diseases but it can not completely prevent crop losses. Therefore, the most effective method of protection against fusarium diseases seems to be cultivation of pest resistant cereal cultivars $(\mathrm{R} \mathrm{u}$ $\mathrm{ckenb}$ a u e r et al. 2001). According to Mesterhazy (2001), there are seven physiological components of pest resistance, namely: (I) resistance to initial infection, (II) resistance to spread within a spike, (III) resistance to kernel infestation (IV) resistance to drying-up, (V) resistance to ear necrosis above the site of infection, (VI ) resistance to toxin accumulation, (VII) tolerance. The investigation conducted in Germany (Lower Saxony) proved that the main factor which controls contamination of grain with mycotoxins (produced by fungi of the Fusarium genus) is an appropriate preceding crop, followed by proper selection of plant cultivars and the method of cultivation ( $\mathrm{K} \mathrm{o} \mathrm{c} \mathrm{h}$ et al. 2006). Nevertheless, the main factor, which determines the frequency of occurrence of fusarium ear diseases, is the level of precipitation in the course of the wheat flowering stage. Moreover, it was found that climate conditions influence competitiveness between fungi species (D o o h a n et al. 2003). Some authors, comparing particular tillage systems, report that the ploughless cultivation system promotes the intensity

\footnotetext{
${ }^{1}$ This study was carried out under project 2.4 of IUNG-PIB's multi-annual programme.
} 
of ear infection (Dill- M a cky and J one s, 2000; $\mathrm{Ch}$ a m peil et al. 2004). Other papers point out the fact that a reduction in the frequency of occurrence of wheat diseases caused by Fusarium ssp. can be achieved by simplified tillage systems. Fungi of the Fusarium genus feature diverse invasiveness and mutual competitiveness (P e t t it t et al. 2003). Particular plant cultivars differ in their immunity to Fusarium ss. (K o c h et al. 2006).

The infection of grain is, to a high degree, related to the infection of the culm base (B a t e $\mathrm{m}$ a n et al. 2007). The latter one, when infected by Fusarium culmorum, $F$. avenaceum or $F$. graminearum, can cause a disease of the whole wheat stem as well as of the ear (C le ment and Pary 1998, S c hlüter et al., 2006). Competitiveness of fungi belonging to Fusarium ssp. can considerably vary depending on the tillage system. The aim of the study was to estimate the occurrence of Fusarium ssp. fungi on the culm base of wheat as dependent on weather conditions, forecrop, tillage system, and plant cultivars grown.

\section{MATERIALS AND METHODS}

The research was carried out in the years 20012003 in Lower Silesia. Field experiments followed the split-split-plot design with 4 replications, on heavy loamy sand soil deposited on a light loamy layer. There were examined three factors, i.e. tillage methods, preceding crop types and wheat cultivars. Factor \# 1 involved different methods of tillage: a) simplified tillage, ploughless, in which the upper layer of soil was loosened down to $15 \mathrm{~cm}$; b) conventional tillage, including ploughing to a depth of $25 \mathrm{~cm}$; and c) direct sowing. Factor \# 2 covered a) oats and b) spring wheat, applied as forecrops. Factor \# 3 related to selected winter wheat (Triticum aestivum L.) cultivars: Elena, Maltanka, Kobra, Aleta, Mikon, Izolda and Sakwa. The forecrops were preceded by corn. In the milky-wax maturity phase (78-81 in the Zadoks scale), out of 100 plants harvested from each experimental plot there were randomly sampled 20 infected stalks for mycological analysis. The sampled plants had their culm-base parts cut off and disinfected with $0.5 \%$ sodium hypochlorite solution for 1 minute. Then, after removal of the top sections, 5 inoculums were cut off which were put on PDA medium in Petri dishes. The operations were carried out in a relatively aseptic environment, according to the commonly accepted standards. The colonies of fungi were identified to determine particular species, as described in the monographs available (B o oth, 1971; N e ls on et all. 1983). Weather parameters in particular years and months of the experiment are shown in Table 1. Meteorological data for IUNG's Experimental Station in Jelcz-Laskowice were obtained from the Institute of
Meteorology and Water Management (IMGW), Wroclaw Branch.

The relations between the number of $F$. culmorum or $F$. avenaceum colonies and the forecrop type, tillage method, wheat cultivar and years of cultivation were evaluated by means of log-linear analysis, according to Everit (1977) and G o od man (1978). All significant differences between the actual and expected values were considered as the evidence of interactions existing between particular factors. To compare the susceptibility of particular cultivars to F. culmorum and $F$. avenaceum infection, depending on different tillage systems and preceding crop types, the correspondence analysis was used. The mentioned analysis enables the presentation of data originally shown in six-dimensional space ( 2 forecrop types $x 3$ tillage systems) in the form of two-dimensional diagrams, in a way which illustrates maximum variability of the genotypes examined. The correspondence analysis enables the assessment of the structure of relations between the tillage systems and forecrops in two-dimensional space, without any loss of information about the variability of the factors in seven-dimensional space, formed by the cultivars examined.

\section{RESULTS}

The optimal statistic model, determining the effect of the selected cultivar and forecrop as well as applied tillage systems on the number of isolates of Fusarium culmorum and $F$. avenaceumn fungi, was analyzed using the $\chi^{2}$ test for general effects and for particular interactions between the factors examined. Because of the fact that statistical values, calculated for the model as interactions of the second, third and fourth order, were significant, the hypothesis about the absence of any effect of year of experiment, tillage system, preceding crop type and winter wheat cultivar on the number of Fusarium culmorum and $F$. avenaceum fungi was rejected et the level $\mathrm{p}<0.01$. The operation of including the interactions of the second and third order did considerably improve matching up the model, which was made evident by significant values of the $\chi^{2}$ test. Significance of the main effects and of particular factors involved the experiment was assessed by data analysis shown in Table 2. The analysis proved considerable differences in the number of isolates of $F$. culmorum or $F$. avenaceum found on wheat cultivars in particular years of investigation. This is the evidence that weather conditions do significantly influence the occurrence of the fungi in question. Moreover, it was shown that the significant variation in number of $F$. aveanceum isolates resulted from the type of forecrop. Yet, the log-linear analysis excludes the interaction between the tillage system and preceding 
crop used. The numerical force of $F$. culmorum or $F$. avenaceum was significantly related to the tillage system, regardless the type of preceding crop applied.

There was introduced an iterative procedure to adjust the model to the actual number of fungi. The procedure was finished when the differences between the model and actual boundary distribution did not exceed the criterion of convergence amounting to 0.01 .

In practice, the procedures described above refine the model by elimination of insignificant interactions between the variable data. Matching up the model requires the calculation of expected values which reflect the boundary numbers of fungi.

In 2003, with increased rainfall during the vegetation season, the wheat cultivars were colonized mostly by $F$. avenaceum, whereas in 2002, after reduced rainfall in September and October 2001, F. culmorum dominated (Tables 1, 3). Oats, applied as a preceding crop, relatively increased the number of $F$. avenace$u m$, as compared to spring wheat (Table 4). However, the number of $F$. culmorum proved to be not affected by the preceding crop type applied. The plough tillage favours the dominance of $F$. culmorum. Direct sowing increased the occurrence of Fusarium avenaceum (Table 5). Particular cultivars of winter wheat differed in their susceptibility to infection of the culm base with $F$. culmorum and $F$. avenaceum. The Kobra cultivar proved to be relatively resistant to $F$. avenaceum, but highly susceptible to infection with the pathogen. Table 5 shows that the Izolda cultivar was considerably resistant to $F$. culmorum.

The further part of the paper is devoted to the determination of the structure of dependence of $F$. culmorum and $F$. avenaceum numbers on the experimental factors analyzed, i.e. precipitation characteristics in the growing season, soil tillage system, preceding crop type as well as plant cultivars. To this end, there was applied the analysis of correspondence, brought into general use by Hill (1974). It is often called analysis of homogeneity or optimal scaling, reciprocal averaging, optimal scaling, quantification method. The analysis aims et presenting a set of points, in our case it is the set of particular cultivars of winter wheat, in the space reduced to two or maximum three dimensions. Therefore, the reaction of individual cultivars to the effects of the analyzed factors is presented in the form of two-dimensional diagrams, with full information about their effects on the frequency of occurrence of $F$. culmorum and $F$. avenaceum, the source of culm base diseases (Figs 1 and 2).

When considering the arrangement of particular wheat cultivars in two-dimensional space (Fig. 1), it is noticeable that the Sakwa, Elena and Mikon cultivars, located on the left side of the system of coordinates, considerably differ in their susceptibility to $F$. avenaceum from the Kobra and Maltanka cultivars located on the right side. The Aleta cultivar differs in its reaction to the fungi responsible for culm base diseases, as compared to other genotypes. The point attributed to Izolda is located close to the origin of the coordinate system. It means that the cultivar profile represents average susceptibility to fusariosis infection. A comparison between Fig. 1 and Fig. 2 leads to the conclusion that the number of occurrence of $F$. culmorum and $F$. avenaceum on the culm base parts of plants significantly differs depending on the soil tillage system used. The evidence for this statement is a considerable distance between the respective points in two-dimensional space. The considerable distances between the points related to particular tillage systems show that there are different effects of tillage systems on the variability of $F$. avenaceum and $F$. culmorum numbers (Figs 3, 4).

Table 1

Total rainfall $(\mathrm{mm})$ and air temperature $\left({ }^{\circ} \mathrm{C}\right)$ during the wheat growing period ( $\mathrm{T}$ - temperature, $\mathrm{O}$ - precipitation)

\begin{tabular}{|c|c|c|c|c|c|c|c|c|c|c|c|c|c|c|}
\hline \multirow{2}{*}{\multicolumn{2}{|c|}{ Year }} & \multicolumn{12}{|c|}{ Month } & \multirow[t]{2}{*}{ Total } \\
\hline & & 9 & 10 & 11 & 12 & 1 & 2 & 3 & 4 & 5 & 6 & 7 & 8 & \\
\hline 2002/ & $\mathrm{T}$ & 16.5 & 9.1 & 2.2 & 1.3 & -1.0 & 3.3 & 4.7 & 11.8 & 15.6 & 18.1 & 16.7 & 18.5 & 116.8 \\
\hline 2003 & $\mathrm{O}$ & 33.5 & 24.3 & 36.3 & 36.1 & 34.6 & 34.6 & 76.9 & 17.8 & 76.5 & 38.1 & 165.8 & 45.4 & 619.9 \\
\hline 2001/ & $\mathrm{T}$ & 12.8 & 12.1 & 6.5 & 2.0 & 0.0 & 0.9 & 3.2 & 7.7 & 14.8 & 15.1 & 19.2 & 19.4 & 113.7 \\
\hline 2002 & $\mathrm{O}$ & 17.3 & 10.9 & 47.9 & 34.8 & 20.7 & 18.1 & 60.3 & 40.9 & 68.8 & 71.0 & 140.8 & 46.7 & 578.2 \\
\hline $2000 /$ & $\mathrm{T}$ & 12.5 & 12.1 & 3.4 & -2.2 & -0.2 & 4.3 & 5.0 & 8.3 & 17.2 & 18.1 & 20.5 & 20.4 & 119.4 \\
\hline 2001 & $\mathrm{O}$ & 79.2 & 22.5 & 33.2 & 31.4 & 24.0 & 58.2 & 15.9 & 44.5 & 78.8 & 53.1 & 38.2 & 85.5 & 565.1 \\
\hline $1956-2000$ & $\mathrm{~T}$ & 13.5 & 8.8 & 3.7 & 0.1 & -1.5 & -0.3 & 3.2 & 8.0 & 13.3 & 16.6 & 18.2 & 17.5 & 101.1 \\
\hline & $\mathrm{O}$ & 47.6 & 38.4 & 38.3 & 34.3 & 27.2 & 25.5 & 31.3 & 37.6 & 61.3 & 71.4 & 80.0 & 67.7 & 560.6 \\
\hline
\end{tabular}


Table 2

Tests of partial association and interaction between investigated factors.

\begin{tabular}{|c|c|c|c|c|c|}
\hline \multirow{4}{*}{ Effect } & \multirow{4}{*}{$\begin{array}{l}\text { Degrees of } \\
\text { freedom }\end{array}$} & \multicolumn{2}{|c|}{ Fusarium culmorum } & \multicolumn{2}{|c|}{ Fusarium avenaceum } \\
\hline & & $\chi^{2}$ & & $\chi^{2}$ & \\
\hline & & Partial & $\mathrm{P}$ & Partial & $\mathrm{P}$ \\
\hline & & association & & association & \\
\hline Cultivar (1) & 6 & 125.35 & 0.0000 & 102.11 & 0.0000 \\
\hline Forecrop (2) & 1 & 1.11 & 0.2921 & 26.27 & 0.0000 \\
\hline Years (3) & 2 & 3185.41 & 0.0000 & 454.62 & 0.0000 \\
\hline Tillage systems (4) & 2 & 21.65 & 0.0000 & 58.36 & 0.0000 \\
\hline $1 \times 2$ & 6 & 45.99 & 0.0000 & 66.83 & 0.0000 \\
\hline $1 \times 3$ & 12 & 37.83 & 0.0001 & 156.76 & 0.0000 \\
\hline $1 \times 4$ & 12 & 83.60 & 0.0000 & 35.18 & 0.0004 \\
\hline $2 \times 3$ & 2 & 5.13 & 0.0769 & 53.45 & 0.0000 \\
\hline $2 \times 4$ & 2 & 2.958 & 0.2278 & 0.72 & 0.6963 \\
\hline $3 \times 4$ & 4 & 94.18 & 0.0000 & 100.47 & 0.0000 \\
\hline $1 \times 2 \times 3$ & 12 & 24.40 & 0.0179 & 175.80 & 0.0000 \\
\hline $1 \times 2 \times 4$ & 12 & 55.12 & 0.0000 & 58.59 & 0.0000 \\
\hline $1 \times 3 \times 4$ & 24 & 116.27 & 0.0000 & 269.45 & 0.0000 \\
\hline $2 \times 3 \times 4$ & 4 & 9.48 & 0.0502 & 16.18 & 0.0027 \\
\hline
\end{tabular}

Table 3

Variability of the number of $F$. avenaceum and $F$. culmorum in particular years of investigation

\begin{tabular}{|c|c|c|c|c|c|c|c|c|}
\hline & \multicolumn{8}{|c|}{ Cultivars vs. F. avenaceum } \\
\hline & Elena & Maltanka & Kobra & Aleta & Mikon & Izolda & Sakwa & Total \\
\hline 2001 & 110 & 262 & 76 & 140 & 190 & 161 & 145 & 1084 \\
\hline 2002 & 37 & 58 & 30 & 89 & 45 & 55 & 126 & 440 \\
\hline 2003 & 180 & 192 & 177 & 173 & 149 & 186 & 228 & 1285 \\
\hline \multirow[t]{3}{*}{ Total } & 327 & 512 & 283 & 402 & 384 & 402 & 499 & 2809 \\
\hline & \multicolumn{8}{|c|}{ Cultivars vs. $F$. culmorum } \\
\hline & Elena & Maltanka & Kobra & Aleta & Mikon & Izolda & Sakwa & Total \\
\hline 2001 & 133 & 82 & 119 & 64 & 142 & 109 & 91 & 740 \\
\hline 2002 & 387 & 384 & 462 & 276 & 378 & 214 & 322 & 2423 \\
\hline 2003 & 0 & 2 & 5 & 0 & 3 & 5 & 4 & 19 \\
\hline Total & 520 & 468 & 586 & 340 & 523 & 328 & 417 & 3182 \\
\hline
\end{tabular}

Table 4

Variability of the number of $F$. avenaceum and $F$. culmorum as dependent on forecrop

\begin{tabular}{|c|c|c|c|c|c|c|c|c|}
\hline \multirow[b]{2}{*}{$\begin{array}{l}\text { Preceding } \\
\text { crop }\end{array}$} & \multicolumn{8}{|c|}{ Cultivars vs. $F$. avenaceum } \\
\hline & Elena & Maltanka & Kobra & Aleta & Mikon & Izolda & Sakwa & Total \\
\hline Oats & 206 & 227 & 139 & 227 & 194 & 256 & 293 & 1542 \\
\hline Wheat & 121 & 285 & 144 & 175 & 191 & 146 & 206 & 1268 \\
\hline \multirow[t]{2}{*}{ Total } & 327 & 512 & 283 & 402 & 384 & 402 & 499 & 2809 \\
\hline & \multicolumn{8}{|c|}{ Cultivars vs. F. culmorum } \\
\hline $\begin{array}{l}\text { Preceding } \\
\text { crop }\end{array}$ & Elena & Maltanka & Kobra & Aleta & Mikon & Izolda & Sakwa & Total \\
\hline Oats & 268 & 270 & 303 & 140 & 251 & 118 & 211 & 1561 \\
\hline Wheat & 252 & 198 & 283 & 200 & 272 & 210 & 206 & 1621 \\
\hline Total & 520 & 468 & 586 & 340 & 523 & 328 & 417 & 3182 \\
\hline
\end{tabular}


Table 5

Variability of the number of $F$. avenaceum and F. culmorum as dependent on tillage system

\begin{tabular}{lrrrrrrrr}
\hline \multicolumn{1}{c}{ Cultivars vs. F. avenaceum } & \multicolumn{1}{c}{} \\
\hline Tillage type & Elena & Maltanka & Kobra & Aleta & Mikon & Izolda & Sakwa & Total \\
\hline Ploughing & 114 & 159 & 59 & 123 & 106 & 131 & 136 & 828 \\
\hline Simplified & 70 & 157 & 93 & 135 & 132 & 112 & 150 & 849 \\
\hline No-tillage & 143 & 196 & 131 & 144 & 146 & 159 & 213 & $\mathbf{1 1 3 2}$ \\
\hline Total & $\mathbf{3 2 7}$ & 512 & $\mathbf{2 8 3}$ & 402 & 384 & 402 & 499 & 2809 \\
\hline & Cultivars vs. F. culmorum & & & & & & & \\
\hline Tillage type & Elena & Maltanka & Kobra & Aleta & Mikon & Izolda & Sakwa & Total \\
\hline Ploughing & 228 & 138 & 162 & 113 & 221 & 124 & 188 & $\mathbf{1 1 7 4}$ \\
\hline Simplified & 151 & 168 & 252 & 96 & 141 & 107 & 135 & 1050 \\
\hline No-tillage & 141 & 162 & 172 & 131 & 161 & 97 & 94 & 958 \\
\hline Total & 520 & 468 & 586 & 340 & 523 & 328 & 417 & 3182 \\
\hline
\end{tabular}

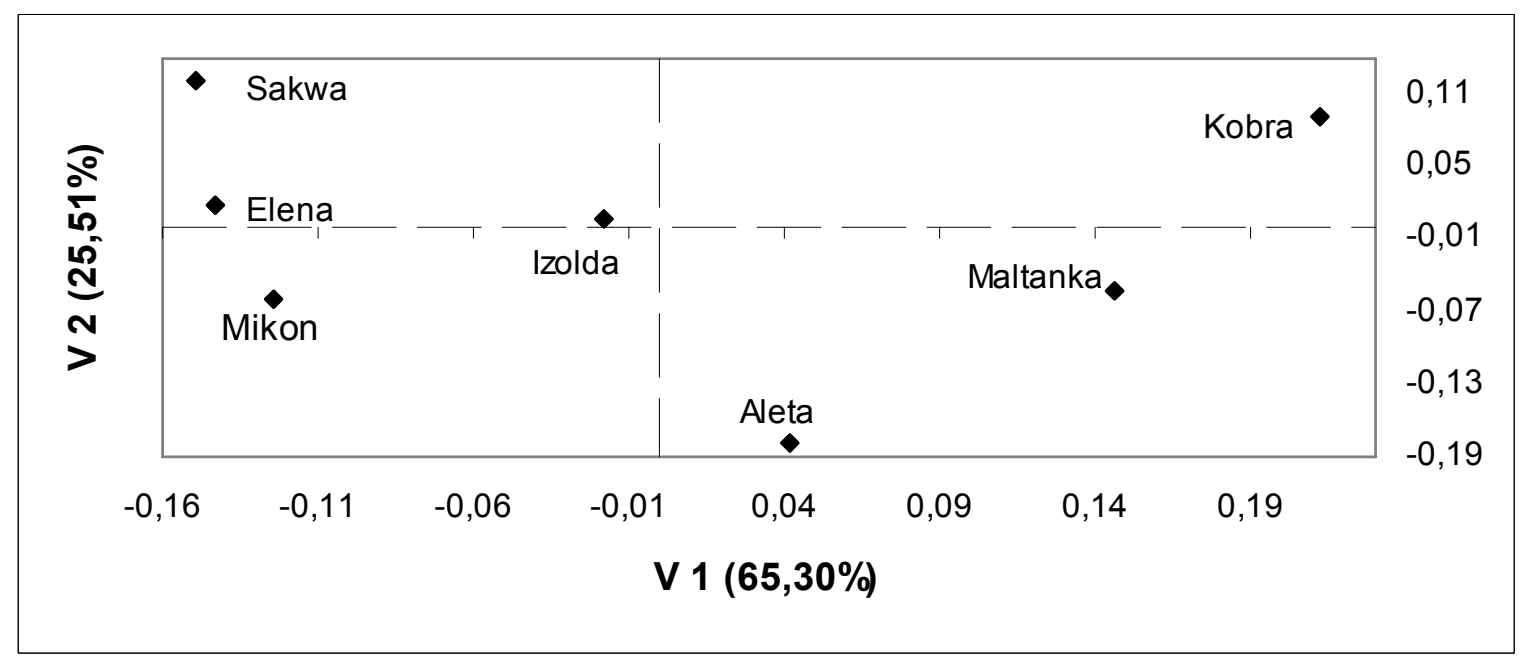

Fig. 1 Variability of susceptibility of particular winter wheat cultivars to $F$. avenaceum infection on the culm base (standardization of row and column profiles) in relation to forecrop type, tillage systems and plant growing season

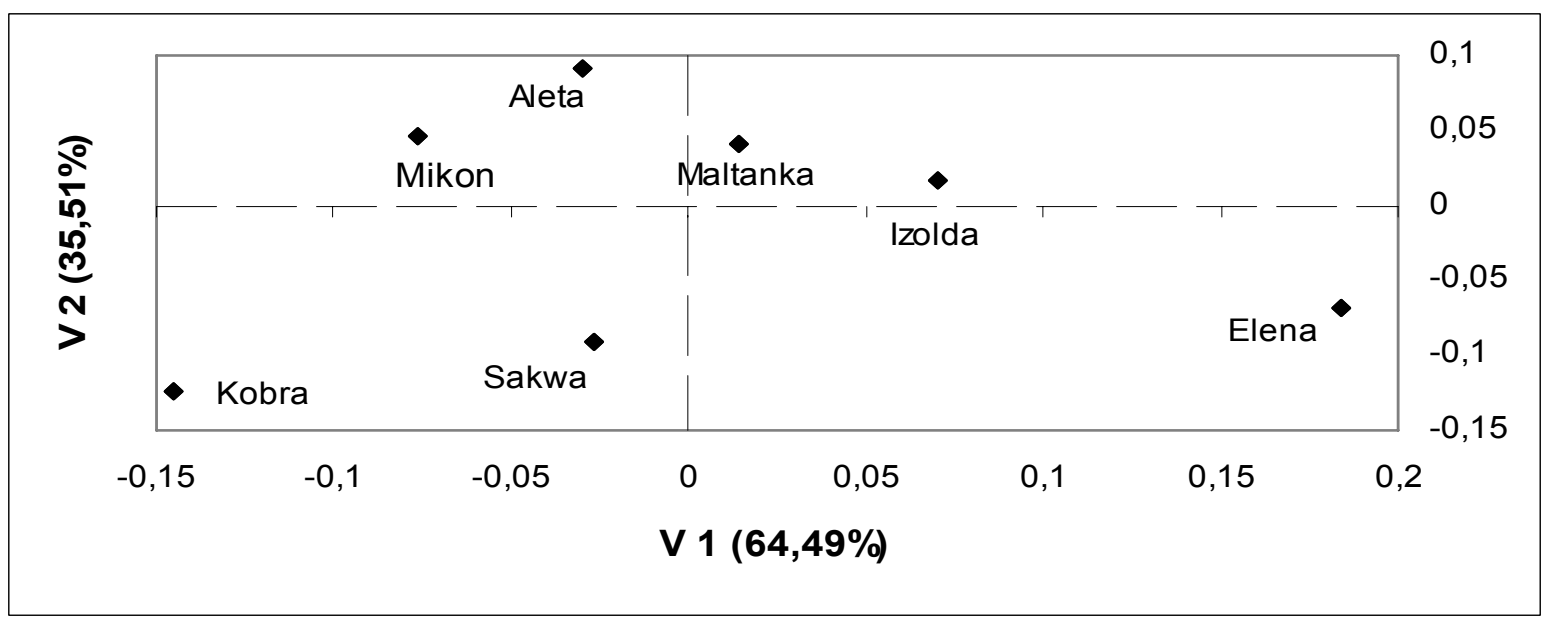

Fig. 2 Variability of susceptibility of particular cultivars of wheat to infection with F. culmorum on the culm base (standardization of row and column profiles) as dependent on forecrop type, tillage systems and plant growing season 


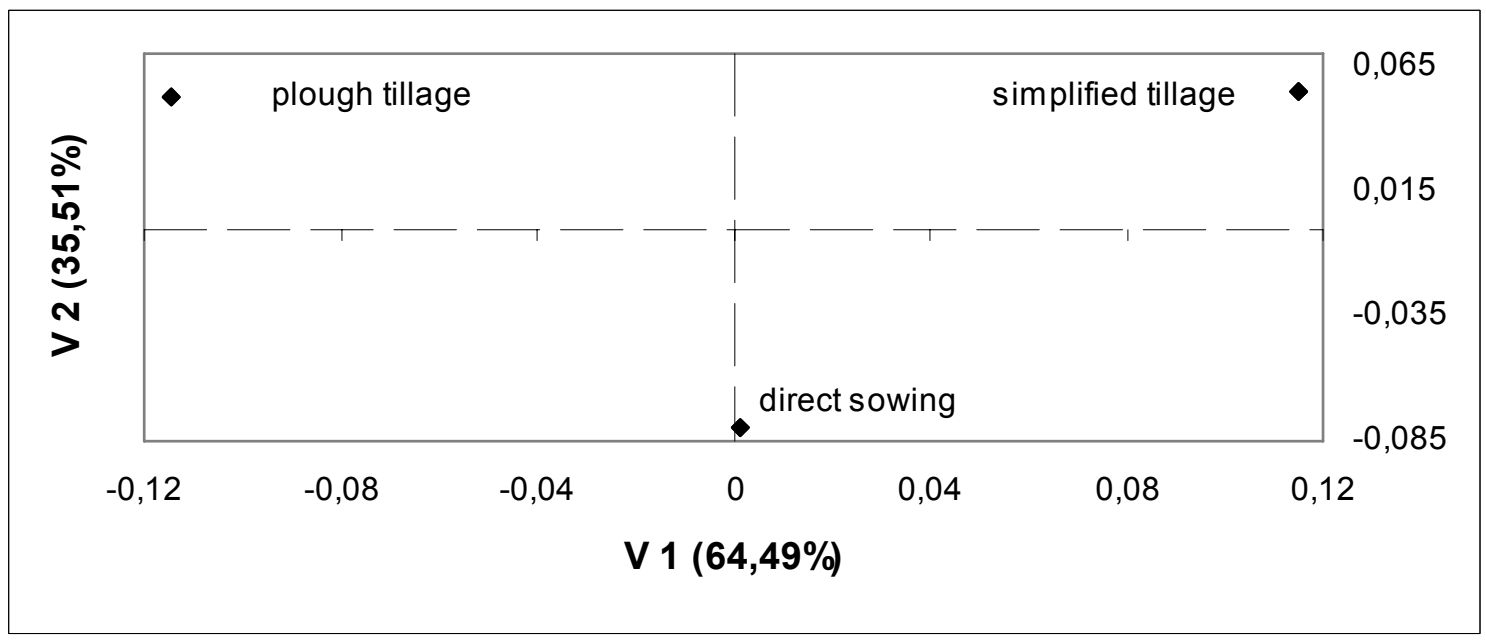

Fig. 3 Variability of tillage systems - infection with F. culmorum on the culm base (standardization of row and column profiles) as dependent on particular cultivars of wheat and plant growing season

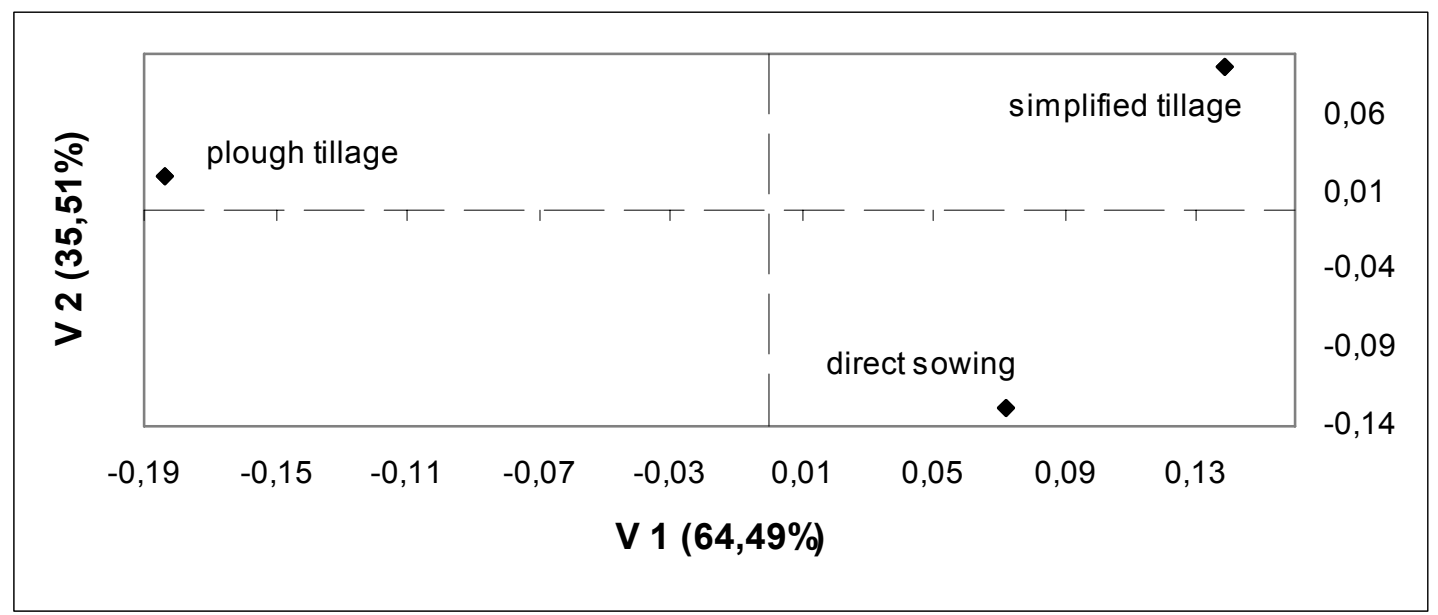

Fig. 4 Variability of tillage systems - infection with $F$. avenaceum on the culm base (standardization of row and column profiles) in dependence on particular cultivars of wheat and plant growing season

\section{DISCUSSION}

The results obtained prove that weather conditions do significantly affect the intensity of occurrence of $F$. avenaceum and $F$. culmorum on wheat. The frequent occurrence of the above-mentioned fungi in Poland is also reported by other authors ( $\mathrm{Go}$ li ńs ki et al. 2002; Ki e cana et al. 2006), while the climatic conditions in Bavaria - Germany, Ireland or Great Britain favour the spread of $F$. poae (X u et al. 2005; B üttne r, 2006). The culm-base parts of wheat cultivars were infected mainly by $F$. culmorum and $F$. avenaceum, whereas $F$. poae, $F$. graminearum and $F$. equiseti were found occasionally. Fusarium culmorum is characterized by relatively small competitiveness, which can explain increased infection of wheat in 2001/2002. September and October
2001 featured steady temperature and relatively low precipitation. Such conditions were advantageous for wheat infection with F. culmorum. In 2003 high precipitation was recorded during the growing period, which promoted the infection with $F$. avenaceum. The occasional occurrence of $F$. graminearum enabled the development of $F$. avenaceum and $F$. culmorum. It is noteworthy that $F$. graminearum is relatively aggressive and occurs predominantly in corn crops in Germany ( $\mathrm{S} \mathrm{chlüter}$ et al. 2006). The differences in the numbers of Fusarium fungi may be explained by the conservative effect of plough tillage (K ö 11 e r and Lin ke, 2001). Ascospores of F. graminearum and $F$. avenaceum, formed on after - harvest residues, can be transported by wind over large distances. The infection with $F$. avenaceum can be considerably reduced by the application of conventional plough 
tillage, which inhibits spores of the fungi. However, such measures will not be effective in the case of predominance of $F$. culmorum. Fungal chlamydospores formed in crop residues, buried by ploughing under a 20-25 cm layer of soil, can survive better in such conditions than on the soil surface. Subsequent ploughing brings the pathogens onto the surface, where they meet optimum conditions for infecting grain ( $\mathrm{S} \mathrm{chl}$ u u t e r et al. 2006). The application of simplified tillage methods, consisting in mixing harvest residues with the upper layer of soil, promotes the growth of antagonistic fungi, bacteria and microbes that decompose straw, which in turn results in a significant reduction in the numerical force of $F$. culmorum compared to typical plough tillage. Unfortunately, without professional support by a phytopathologist, farmers could not be able to put this knowledge into practice. This is the reason why in Poland, under the current climatic conditions and with typical crop rotation, we recommend energy-saving, long-lasting simplified tillage which prevents the occurrence of many fungal diseases.

\section{REFERENCES}

Bateman G.L., Gutteridge R.J., Gherbawy Y., Thomsett M.A., Nichols on P. 2007. Infection of stem bases and grains of winter wheat by Fusarium culmorum and Fusarium graminearum and effects of tillage method and maize - stalk residues. Plant Pathol. 56 (4) : 604-615.

Büttne r P. 2006. Das Artenspektrum der Gattung Fusarium an Weizen und Roggen in Bayern in den Jahren 2003 und 2004. Gesunde Pflanzen. 58 : 28-33.

Clement J.A., Parry D.W. 1998. Stem-base disease and fungal colonization of winter wheat grown in compost inoculated with Fusarium culmorum, Fusarium graminearum and Microdochium nivale. Eur. J. Plant Pathol. 104: 323-330.

Champeil A., Fourbelt J.F., Dorě T., Roosingnol L. 2004. Influence of cropping system on Fusarium heat blight and mycotoxin levels in winter wheat. Crop Prot. 23, (6): 531-537.

Dill-Macky R., Jones R.K. 2000. The effect of previous crop residues and tillage on Fusarium head blight of wheat. Plant Dis. 84: 71-76.

Doohan F.M., Brennan J., Cooce B.M. 2003. Influence of climatic factors on Fusarium species pathogenic to cereals. Eur. J. Plant Pathol. 109 : 755-768.

Goliński P, Kaczmarek Z., Kiecana I., Wiśniewska H., Kaptur P., Kostecki M., Chełkowski J. 2002. Fusarium heat blight of common Polish winter wheat cultivars - comparison of effects of Fusarium avenaceum and Fusarium culmorum on yield components. J. Phytopathol. 50 (3): 135-141.

Inch S.A., Gilbert J. 2003. Survival of Gibberella zeae in Fusarium - damaged wheat kernels. Plant Dis. 87 (3): 282-287.
Kiecana I., Mielniczuk E., Cegiełko M. 2006. Badania podatności kłosów pszenicy ozimej przez $\mathrm{Fu}$ sarium avenaceum (FR.). / Studies on the susceptibility of winter wheat ears to the infection by Fusarium avenaceum (FR.). Acta Agrophisica 8 (3): 629-636.

Koch H.J., Pringas Ch., Maerlaender B. 2006. Evaluation of environmental and management effects on Fusarium head blight infection and deoxynivalenol concentration in the grain of winter wheat. Eur. J. Agron. 24 (4): 357-366.

Köller K., Linke Ch. 2001. Erfolgreicher Ackerbau ohne Pflug; Anbaupraxis. Deutschland, Frankfurt an Main, DLG Verlag: 79-130.

Mesterhazy A. 2001. Breeding for Fusarium heat blight resistance in wheat. Wheat in Global Environment. Proceedings of the $6^{\text {th }}$ International Wheat Conference, 5-9 June 2000, Budapest, Hungary : 353-358.

Martin R.A., Johnston H.W. 1982. Effects and control of Fusarium diseases of cereal grains in the Atlantic Provinces. Can. J. Plant Pathol. 4: 210-216.

Pettitt T., Xu X., Parry D. 2003. Association of Fusarium species in the wheat stem rot complex. Eur. J. Plant Pathol. 109: 769-774.

Ruckenbauer P., Buerstmayr H., Lemmens M. 2001. Present strategies in resistance breeding against scab (Fusarium ssp.). Euphytica 119: 121-127.

Schlüter K., Kropf U., Karlowsky P. 2006. Untersuchungen zur systemischen Infektion von Fusarium culmorum an Winterweizen in Schleswig-Holstein. Gesunde Pflanzen. 58 (2) : 107-116.

Xu XM, Parry DW, Nicholson P., Thomsett MA., Simpson D., Edwards SG. Cooke BM, Giczey G., Tatnell J. 2005. Predominance and association of pathogenic fungi causing $\mathrm{Fu}$ sarium ear blight in wheat in four European countries. Eur. J. Plant Pathol. 112: 143-154.

\section{Wpływ sposobu uprawy roli i rodzaju przedplonu na częstotliwość występowania Fusarium culmorum i $F$. avenaceum u podstaw źdźbła wybranych odmian pszenicy ozimej}

\section{Streszczenie}

W latach 2001 - 2003 analizowano zależności pomiędzy liczebnością Fusarium culmorum i $F$. avenaceum, grzybów występujących u podstawy źdźbła, siedmiu odmian pszenicy ozimej i rodzajem przedplonu oraz systemem uprawy. Badania przeprowadzono w Polsce, na poletkach z lekką glebą w dolnośląskiej stacji doświadczalnej należącej do Instytutu Uprawy Nawożenia i Gleboznawstwa w Puławach (IUNG). Analiza logarytmiczno-liniowa i korespondencji dowiodła zróżnicowanej odporności poszczególnych odmian pszenicy na grzyby $F$. culmorum 
i $F$. avenaceum. Zaobserwowano również znaczne różnice $\mathrm{w}$ fuzariozach pszenicy $\mathrm{w}$ zależności od wielkości opadów atmosferycznych i temperatury w trakcie sezonu wegetacyjnego roślin. Odmiana Kobra była wysoce odporna na $F$. avenaceum. Najmniejsze ilości grzybów $F$. culmorum stwierdzono u podstawy źdźbła odmiany Izolda. Uprawa kukurydzy jako przedplonu owsa i pszenicy jarej w znacznym stopniu różnicowała występowanie gatunków grzybów w badanych systemach uprawy. W uprawie płużnej pszenica była porażona głównie przez Fusarium culmorum, podczas gdy w przypadku siewu bezpośredniego poszczególne odmiany pszenicy były w większości porażone przez F. avenaceum. 